\title{
Contamination of polycyclic aromatic hydrocarbons (PAHs) in urban soils in Beijing, China
}

\author{
Lily Tang a,b, Xiang-Yu Tang ${ }^{\text {a }}$, Yong-Guan Zhu ${ }^{\text {a,* }}$, Ming-Hui Zheng ${ }^{\text {a }}$, Qi-Long Miao ${ }^{\mathrm{b}}$ \\ ${ }^{\mathrm{a}}$ Research Center for Eco-Environmental Sciences, Chinese Academy of Sciences, Beijing 100085, China \\ ${ }^{\mathrm{b}}$ Nanjing Institute of Meteorology, Nanjing 210044, China
}

Available online 1 July 2005

\begin{abstract}
Soil contamination with polycyclic aromatic hydrocarbons (PAHs) is an increasing problem in many countries, including China. An extensive and systematic survey has been undertaken to evaluate the contamination with PAHs of urban soils in Beijing, China. Soil samples were collected from campuses of universities, schools and kindergartens, public squares, fallow land and roadsides, and were analyzed for 16 PAHs by GC-MS. There was a high variability in the total PAHs ( $\sum$ PAHs) concentrations, ranging from less than 366 to $27,825 \mathrm{ng} \mathrm{g}^{-1}$. The highest $\sum$ PAHs concentrations were found at roadsides and industrial sites. Soil organic carbon (SOC) is one of the important factors that can influence the concentrations of PAHs in soils. It was found that concentrations of $\sum$ PAHs were significantly correlated with that of soil organic carbon. To trace the sources of PAHs, the ratios of phenanthrene to anthracene and fluoranthene to pyrene were used to identify pyrogenic and petrogenic sources, respectively. In most cases, PAHs in soils in urban areas of Beijing were pyrogenic. These sources included motor vehicle exhausts, industrial activities and coal burning. These data can be further used to assess the health risk associated with soils polluted with PAHs.

(C) 2005 Elsevier Ltd. All rights reserved.
\end{abstract}

Keywords: PAHs; Soil; Distribution; Source identification; Organic carbon

\section{Introduction}

Polycyclic aromatic hydrocarbons (PAHs), a group of stable chemicals, are ubiquitous organic contaminants in environments, such as sediments and soils (Hoffman et al., 1984; Jones, 1991; Wild and Jones, 1993; Baumard et al., 1998; Ribes et al., 2003). They have been listed as priority pollutants by both the US Environmental Protection Agency (EPA) and European Union (EU). While PAHs can occur naturally, mostly they are originated from anthropogenic processes, such as burning of fossil fuels and other organic substances (Simoneit, 1977; Wakeham et al., 1980a,b). PAHs containing two or more rings usually have high stability in the environments. Due to the high hydrophobicity and stable chemical structure, PAHs are not very soluble and can be adsorbed rapidly onto soil

\footnotetext{
* Corresponding author. Fax: +86 1062923563.

E-mail address: ygzhu@mail.rcees.ac.cn (Y.-G. Zhu).
}

particles, particularly on soil organic matter (Means et al., 1980). PAHs in soils can be dispersed by surface runoff and dust production; soils can therefore be considered as one of the pollution sources for PAHs contamination in air and sediments (Mai et al., 2003). Soil types and properties such as organic carbon play the most important role in the adsorption of PAHs in soils (McGroddy and Farrington, 1995; Jonker and Smedes, 2000).

It has been well established that PAHs have carcinogenic, mutagenic and teratogenic effects on animals (Hoffman and Wynder, 1971; Grimmer, 1983; Perera, 1997). This has led to intensive research into their chemical and biological properties in the environments, and the mechanisms by which these physiological effects are produced. For the assessment of environmental risks associated with soil contamination with PAHs, it is important to evaluate the spatial distribution and pathways (sources) of PAHs in soils. Molecular indices based on individual compound concen- 
trations were developed to assess the various origins of these compounds (Solco, 1986; Sicre et al., 1987).

As anthropogenic activities are the main sources of PAHs, the levels of PAHs in soils in urban areas are approximately a factor of 2-10 higher than those in rural areas (Lodovici et al., 1994; Wagrowski and Hites, 1997). PAHs contamination in soils close to highways has been found to be similar to those in urban areas (Wang and Meresz, 1982). Beijing, located in northern China, is a densely populated city with a heavy load of vehicular traffics and major industrial plants within the metropolitan area. However, up to now, little information is available on the PAHs contamination in urban soils of Beijing (Chu et al., 2003). The purpose of this study is therefore to identify the levels of PAHs in topsoils in some key areas of Beijing in order to establish an environmental evaluation, which will be served as essential reference information for future studies, such as remediation technologies, health risk assessment and urban development.

\section{Materials and methods}

\subsection{Area description and sampling procedure}

Soils used in this study were collected from eight main municipal zones in urban areas of Beijing (Fig. 1). These sampling areas could be categorized into different functional sections, such as campuses of universities, schools and kindergartens, public squares, fallow land and roadsides where people always play and rest on. At each site, six samples (at the depth of $0-5 \mathrm{~cm}$ ) were collected randomly, and were bulked together to form one composite sample. All samples were air-dried at room temperature after transported to the lab within $4 \mathrm{~h}$. Air-dried soil samples were crushed to pass 2-mm mesh sieve and homogenized, then sealed in Kraft paper envelopes or in solvent-cleaned glass containers and stored at $-20{ }^{\circ} \mathrm{C}$ until analysis.

\subsection{Chemical analysis}

All solvents purchased from Beijing Chemical Factory were of analytical grade and redistilled in all glass system before use. The stock reference standard mixture of 16 PAHs (Supelco Co., Cat. No. 47930-U) includes naphthalene, acenaphthylene, 2-bromonaphthalene, acenaphthene, fluorene, phenanthrene, anthracene, fluoranthene, pyrene, benz( $a$ )anthracene, chrysene, $\operatorname{benzo}(b)$ fluoranthene, benzo( $a$ )pyrene, indeno(123-cd)pyrene, dibenz(ah) anthracene, and benzo( $g h i)$ perylene at a concentration of $2000 \mathrm{mg}$ $\mathrm{L}^{-1}$, respectively. Silica gel (60-100 mesh) purchased from Qingdao Haiyang Chemical Co. (Shangdong, China) was activated at $130{ }^{\circ} \mathrm{C}$ for $10 \mathrm{~h}$, then kept in a desiccator.

Ten grams of the soil sample was weighed precisely and mixed with $2 \mathrm{~g}$ anhydrous sodium sulfate. The sample was Soxhletextracted for $24 \mathrm{~h}$ with $160 \mathrm{ml}$ dichloromethane/acetone solvent $(7: 9 \mathrm{v} / \mathrm{v})$. The solvents were removed using a rotary evaporator and the volume was reduced to ca. $1 \mathrm{ml}$ under nitrogen. The extract was then cleaned using silica adsorption chromatography capped with anhydrous sodium sulfate and eluted with $60 \mathrm{ml}$ mixture of hexane and pentane $(6: 4 \mathrm{v} / \mathrm{v})$. Afterward, this extract was reduced to $1 \mathrm{ml}$ under nitrogen for analysis of PAHs.

The final concentrated extracts from the environmental samples were analyzed using a Hewlett Packard 6890 gas chromatography equipped with a splitless injector, HP-5 capillary column ( $60 \mathrm{~m} \times 0.25 \mathrm{~mm}$ i.d. with $0.25 \mu \mathrm{m}$ film thickness) and a 5973 mass spectrometer detector. The carrier gas was helium (ultra high purity) at a flow rate of $1.1 \mathrm{ml} / \mathrm{min}$, while oven was programmed from $90{ }^{\circ} \mathrm{C}$ (held for $2 \mathrm{~min}$ ) initially to $200{ }^{\circ} \mathrm{C}$ (held for $5 \mathrm{~min}$ ) at a rate of $10{ }^{\circ} \mathrm{C} / \mathrm{min}$ and then to $300{ }^{\circ} \mathrm{C}$ (held for 15

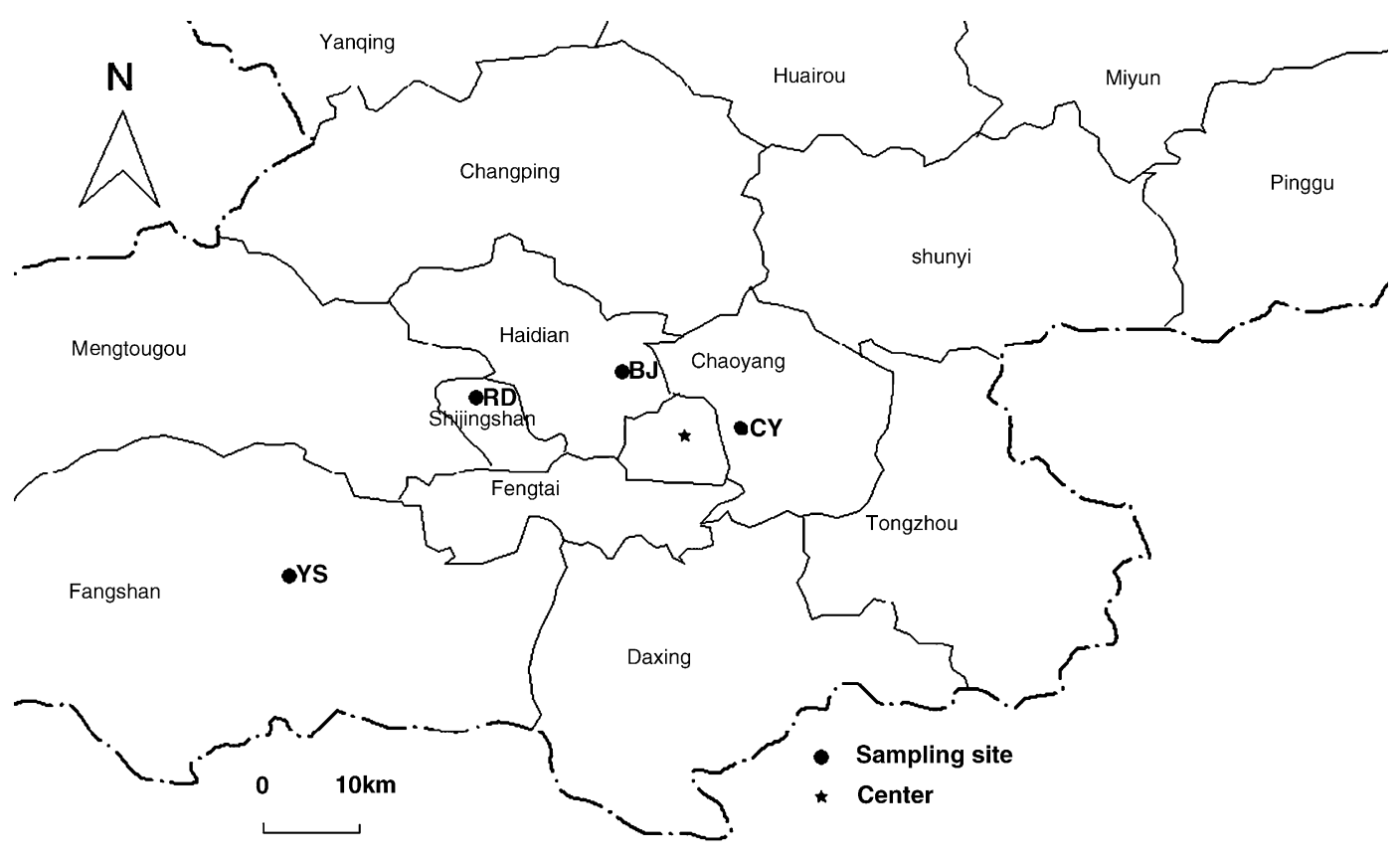

Fig. 1. Schematic map showing the soil sampling sites in the urban areas of Beijing City. 
$\min$ ) at a rate of $3{ }^{\circ} \mathrm{C} / \mathrm{min}$. The injector temperature was held at $290{ }^{\circ} \mathrm{C}$, and the detector temperature was $310{ }^{\circ} \mathrm{C}$. For identification, selected ion monitoring (SIM) mode was carried out using the molecular ions selective for individual PAHs. Chromatographic data were collected and processed using HP Chemstation software. A representative chromatogram of sample was shown in Fig. 2.

Experiments on recovery were carried out by spiking known concentration standards (2000 $\mathrm{ng} \mathrm{g}^{-1}$ ) in uncontaminated soil (previously found containing very low amounts of PAHs), and showed that the average recovery ranged from $81 \%$ for naphthalene to $110 \%$ for benzo $(g h i)$ perylene. The concentration of those to produce a signal-to-noise of 3:1 in blank sample was defined as detection limit (LOD). The LOD for PAHs ranged from $2000 \mathrm{ng}$ $\mathrm{kg}^{-1}$ for naphthalene to $6000 \mathrm{ng} \mathrm{kg}^{-1}$ for benzo( $\mathrm{ghi}$ )perylene.

All soils collected in this study were brown soils. Soil $\mathrm{pH}$ was measured to be 7.03 to 9.15 in $0.01 \mathrm{~mol}^{-1} \mathrm{CaCl}_{2}$ at a soil/solution ratio of $1: 1$. The content of soil organic carbon (SOC) was determined in triplicate using the methods described by Nelson and Sommers (1982). The standard deviation of measurements was $\pm 3 \%$ for soil organic carbon (SOC).

\section{Results and discussion}

\subsection{PAHs contamination levels in urban soils}

A wide range of soil PAHs concentrations was observed (Table 1), from $219 \mathrm{ng} \mathrm{g}^{-1}$ to $27,825 \mathrm{ng} \mathrm{g}^{-1}$ (dry weight), which included those PAHs considered as carcinogens by the US Environmental Protection Agency. The mean concentration of total PAHs in soil samples was $3917 \mathrm{ng} \mathrm{g}^{-1}$ of the sum of the 16 PAHs. The highest pollution levels were observed for soil samples in roadside showing heavy traffics at sites BJ-4 (14,574 $\left.\mathrm{ng} \mathrm{g}^{-1}\right)$

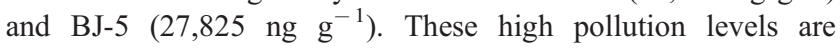
comparable with those found in Beijing's highways (1470 to $6610 \mathrm{ng} \mathrm{g}^{-1}$ ) (Chu et al., 2003), but were significantly lower than values reported on in the Handan city of China (1150 to $480 \mathrm{mg}$ $\mathrm{kg}^{-1}$ ) (Sun et al., 2003). PAHs concentrations near some petrol stations were also high. These stations are always jammed with motor vehicles and close to industrial activities, which explained the relatively high PAHs concentrations at these sites. PAHs in soils collected in this study include compounds with a wide range of molecular weights, from naphthalene to benzo( $g h i)$ perylene. Fig. 3 shows the variation in percentages of PAH compounds with different ring numbers in soils. The BJ-1 to BJ-7 sampling sites are located in the main traffic areas, and the major organic pollutants are mostly dominated by PAHs with 3-5 rings, such as pyrene. Sampling sites from CY-1 to CY-5 and from YS-11 to YS-18 had much less anthropogenic activities, which resulted in the dominance of PAHs with 2 rings. Generally speaking, the concentrations of PAHs with 6 rings were relatively low in most soil samples.

Some environmental standards (criteria or guidance) for PAHs in soil were released by the Netherlands Ministry of Housing, Spatial Planning, and the Environment (De Vries and Bakker, 1998), Canadian Council of Ministers of the Environment (CCME, 1996a,b), British Columbia Ministry of Environment, Lands and Parks (BCME, 1996), and The Ontario Ministry of Environment and Energy (MOEE, 1996), for assessing risk at contaminated sites, clean-up goals, and monitoring remediation efforts, as shown in Table 2. About $61 \%$ of collected soils in Beijing were associated with PAHs concentrations over $1 \mu \mathrm{g} \mathrm{g}^{-1}$, which was set to be the soil target value for total 10 PAHs concentration by the Netherlands, indicating their potential risk to human health. However, such environmental standards for PAHs in soil are not established yet in many countries, including China.

\subsection{Source of the PAHs contamination}

Combustion processes and release of un-combusted petroleum products are the two main sources of anthropogenic PAHs found in the environment. In general, parent PAHs are largely produced by incomplete combustion of fossil fuels and plant materials or natural diagenesis (Yunker et al., 1996). To distinguish the natural and anthropogenic PAHs inputs in soils, we used PAHs compositions (parent, alkyl and vascular plant PAHs) and their ratios as a way to discriminate PAHs sources (Yunker et al., 1999; Sanders et al., 2002). The usefulness of these indices relies on the fact that during low temperature processes such as catagenesis of organic matter leading to the formation of petroleum, the PAHs distribution is governed by thermodynamic properties. For high temperature processes, such as pyrolysis of organic matter, their distribution is

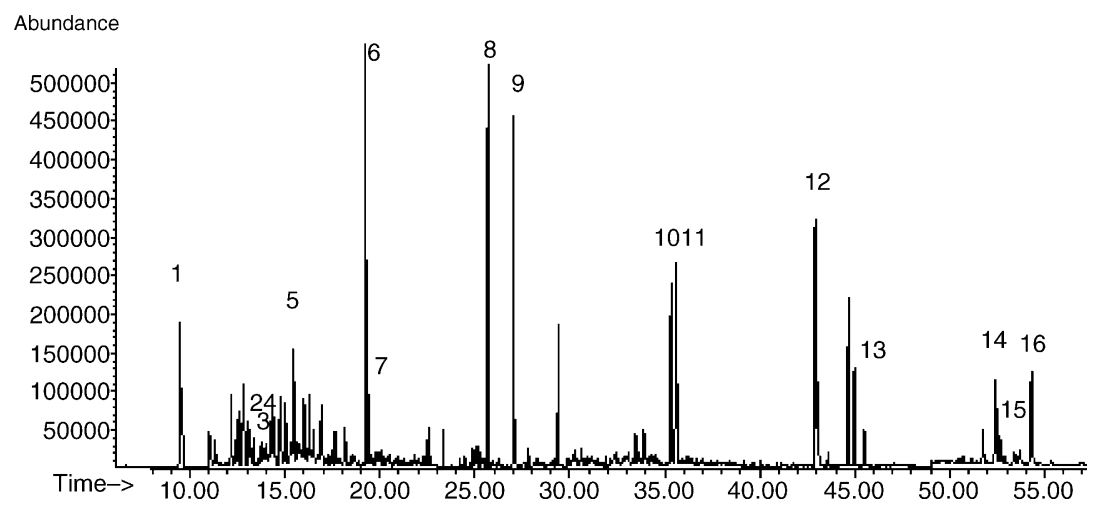

Fig. 2. A representative chromatogram of 16 PAHs from a soil sample. $(1=$ naphthalene, $2=$ acenaphthylene, $3=2$-bromonaphthalene, $4=$ acenaphthene, $5=$ fluorene, $6=$ phenanthrene, $7=$ anthracene, $8=$ fluoranthene, $9=$ pyrene, $10=\operatorname{benzo}(a)$ anthracene, $11=\operatorname{chrysene}, 12=\operatorname{benzo}(b)$ fluoranthene, $13=\operatorname{benzo}(a)$ pyrene, $14=$ indeno(123-cd)pyrene, $15=\operatorname{dibenz}(a h)$ anthracene, $16=\operatorname{benzo}(g h i)$ perylene $)$. 
Table 1

Total polycyclic aromatic hydrocarbons and selected PAH ratios in each sample

\begin{tabular}{|c|c|c|c|c|c|c|}
\hline \multicolumn{2}{|c|}{ Sampling sites } & \multirow{2}{*}{$\frac{\text { Total PAHs }\left(\mathrm{ng} \mathrm{g}^{-1}\right)}{4018.4}$} & \multirow{2}{*}{$\begin{array}{l}\text { Phe/Ant index } \\
10.5\end{array}$} & \multirow{2}{*}{$\frac{\text { Flu/Pyr index }}{1.2}$} & \multirow{2}{*}{$\frac{\mathrm{SOC}(\%)}{2.5}$} & \multirow{2}{*}{$\frac{\text { Dominant Origin }}{\text { Pyro }^{a} \text { and Petro }}$} \\
\hline CY-1 & University & & & & & \\
\hline CY-2 & University & 1725.1 & $\mathrm{ND}^{\mathrm{c}}$ & 1.3 & 1.7 & Pyro \\
\hline CY-3 & Bus station & 8036.7 & 10.5 & 1.2 & 4.3 & Pyro and Petro \\
\hline CY-4 & Residential area & 3450.2 & ND & 1.3 & 2.3 & Pyro \\
\hline CY-5 & Playground & 219.7 & 1.0 & ND & 0.8 & Pyro \\
\hline RD-1 & Public squares & 575.4 & 7.9 & 1.3 & 1 & Pyro \\
\hline RD-2 & Residential area & 4269.4 & 18.6 & 1.4 & 2.9 & Pyro and Petro \\
\hline RD-3 & Residential area & 5284.0 & 8.0 & 1.5 & 3.8 & Pyro \\
\hline RD-4 & Residential area & 365.8 & 6.5 & 1.4 & 0.9 & Pyro \\
\hline RD-5 & School & 943.0 & 15.1 & 1.4 & 1.1 & Pyro and Petro \\
\hline RD-6 & School & 658.8 & 14.1 & 1.4 & 1.2 & Pyro and Petro \\
\hline RD-7 & School & 939.1 & 5.5 & 1.3 & 1.2 & Pyro \\
\hline RD-8 & Roadsides & $12,597.9$ & 10.6 & 1.2 & 4.9 & Pyro and Petro \\
\hline RD-9 & Bus station & 2068.4 & 8.8 & 1.2 & 1.7 & Pyro \\
\hline RD-10 & Fallow land & 2534.4 & 11.4 & 1.2 & 2.6 & Pyro and Petro \\
\hline YS-11 & Public squares & 1137.8 & 1.6 & 0.3 & 1.1 & Pyro and Petro \\
\hline YS-12 & Residential area & 543.3 & 1.5 & 0.2 & 0.9 & Pyro and Petro \\
\hline YS-13 & Playground & 1053.2 & 14.6 & 1.3 & 1.3 & Pyro and Petro \\
\hline YS-14 & Kindergarten & 1350.4 & 13.2 & 1.3 & 1.3 & Pyro and Petro \\
\hline YS-15 & Residential area & 1005.7 & 15.6 & 1.5 & 1.2 & Pyro and Petro \\
\hline YS-16 & Roadsides & 1538.4 & 21.7 & 2.1 & 1.6 & Pyro and Petro \\
\hline YS-17 & Public squares & 1321.9 & 6.6 & 1.1 & 1.5 & Pyro \\
\hline YS-18 & Schoolyard & 1431.4 & 3.4 & 0.3 & 2 & Pyro and Petro \\
\hline YS-19 & Roadsides & 2373.0 & 2.8 & 0.2 & 2.6 & Pyro and Petro \\
\hline BJ-1 & Roadsides & 1601.1 & 10.8 & 1.3 & 1.5 & Pyro and Petro \\
\hline BJ-2 & Roadsides & 1590.2 & 8.6 & 1.3 & 1.4 & Pyro \\
\hline $\mathrm{BJ}-3$ & Roadsides & 2894.9 & 6.6 & 1.2 & 2.4 & Pyro \\
\hline BJ-4 & Roadsides & $14,574.0$ & 8.3 & 1.0 & 5 & Pyro \\
\hline BJ-5 & Service station & $27,825.0$ & ND & 1.2 & 6.2 & Pyro \\
\hline BJ-6 & Roadsides & $10,844.9$ & 10.4 & 1.1 & 4.7 & Pyro and Petro \\
\hline BJ-7 & Roadsides & 2661.8 & 9.7 & 1.3 & 2 & Pyro \\
\hline
\end{tabular}

a Pyrogenic source.

b Petrogenic source.

c Not detectable.

governed by kinetic characteristics. Therefore, PAHs distribution is dependent on temperature (Alberty and Reif, 1988). The ratios of phenanthrene/anthracene (Phe/Ant) within the 3-ring PAHs group and fluoranthene/pyrene (Flu/Pyr) within the 4-ring PAHs group were used to form molecular indices (Colombo et al., 1989; Baumard et al., 1998). Phenanthrene is more thermochemically

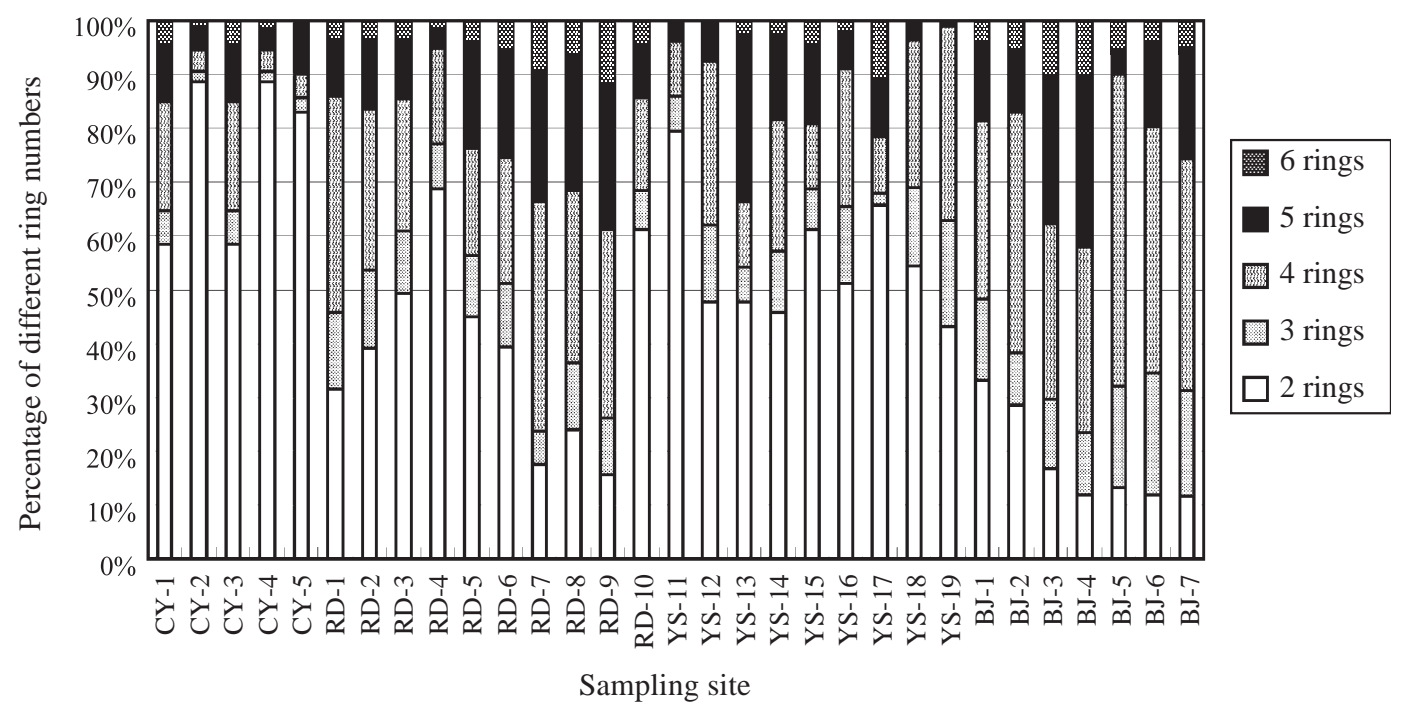

Fig. 3. The distribution of PAHs with different ring numbers in different soil samples collected from urban areas of Beijing, China. 
stable than anthracene, so at low temperature molar fraction of phenanthrene produced is much higher than that of anthracene. High temperature courses, such as the incomplete combustion of organic materials (coal burning, wood burning, vehicular exhaust emission), are characterized by low Phe/Ant ratio values. The discrimination of the origins of PAHs was also performed according to the value of Flu/Pyr.

Usually, Phe/Ant ratio $<10$ and Flu/Pyr ratio $>1$ indicate that PAHs come from pyrogenic source and Phe/Ant $>15$ and Flu/ $\mathrm{Pyr}<1$ indicate petrogenic origins of PAHs (Baumard et al., 1998). The ratios of Phe/Ant and Flu/Pyr are listed in Table 1. The Flu/Pyr ratios in all samples ranged from 0.2 to 2.1 and Phe/Ant ratios ranged from 1.0 to 18.6. Data from each sample were grouped according to the origins of these PAHs in soils. It can be seen that there was a strong pyrogenic influence on soil PAHs in all soils sampled in Beijing. The molecular indices at site RD-8 were 10.6 and 1.2 for Phe/Ant and Flu/Pyr, respectively, indicated a possible influence of petrogenic inputs.

\subsection{Effect of soil organic carbon (SOC)}

Numerous studies have shown that PAHs are strongly retained by the soil matrix (Chung and Alexander, 1998, 2002). The partitioning concept of soil sorption of organic contaminants implies that the sorption of hydrophobic organic molecules is determined by the organic carbon content of the substrate (Karickhof and Brown, 1979; Chiou et al., 1979, 1998). The organic matter content is considered to be a very important variable related to PAHs pollution of soils (Boehm et al., 2002). Soil organic carbon varied greatly between soil samples ranging from $0.8 \%$ to $6.2 \%$ with a mean of $2.4 \%$ (Table 1). The relationship between total concentrations of PAHs in soils and soil organic matter has been extensively investigated. In the present study, soils contained a wide range of SOC, with the lowest $(0.8 \%)$ being found in soil CY-5, and

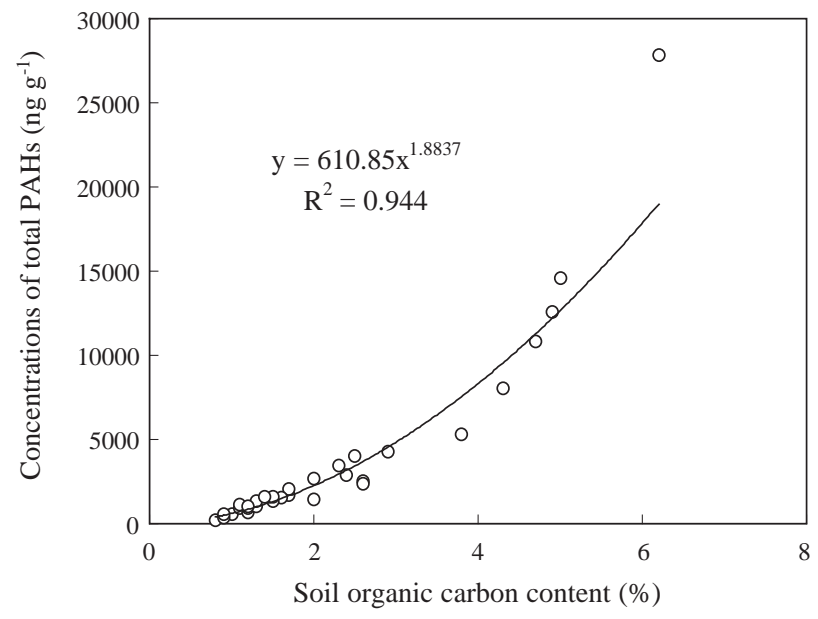

Fig. 4. The relationship between soil organic carbon and total concentrations of PAHs in soil samples at different locations in urban areas of Beijing.

the highest (6.2\%) in soil BJ-5 (Table 1). A regression analysis was conducted to investigate the relationship between the concentrations of the $\sum$ PAHs (16 compounds, $\mathrm{ng}^{-1}$ d.w.) and the amounts of soil organic carbon (SOC, \%). The experimental results showed a positive exponential relationship (Fig. 4). This result demonstrated that higher amounts of PAHs mainly occur in soils with higher SOC, which can be described by the following equation:

$\sum$ PAHs $=610.85 \mathrm{SOC}^{1.8837}, n=31, r^{2}=0.944$

where $\sum$ PAHs is the total concentrations of 16 PAHs in soils (ng $\mathrm{g}^{-1}$ ), and SOC is the amounts of soil organic carbon (\%). This relationship illustrates that the level of soil contamination with PAHs

Table 2

Some published Soil environmental standards for PAHs in soils $\left(\mu \mathrm{g} \mathrm{g}^{-1}\right)$

\begin{tabular}{|c|c|c|c|c|c|c|c|c|c|c|c|c|c|}
\hline Compound name & RIVM TV & $\mathrm{BC} \mathrm{Ag}$ & BC UP & BC R & $\mathrm{BC} \mathrm{C}$ & BC I & CCME Ag & CCME RP & CCME C & CCME I & Ont Ag (C) & Ont RP (C) & Ont IC (C) \\
\hline Acenaphthene & & & & & & & & & & & 15 & 15 & 15 \\
\hline Acenaphthylene & & & & & & & & & & & 100 & 100 & 100 \\
\hline Anthracene & & & & & & & & & & & 28 & 28 & 28 \\
\hline $\operatorname{Benzo}(a)$ anthracene & & 0.1 & 1 & 1 & 10 & 10 & 0.1 & 1 & 10 & 10 & 6.6 & 6.6 & 6.6 \\
\hline Benzo(a)pyrene & & & & & & & 0.1 & 0.7 & 0.7 & 0.7 & 1.2 & 1.2 & 1.9 \\
\hline $\operatorname{Benzo}(b)$ fluoranthene & & 0.1 & 1 & 1 & 10 & 10 & 0.1 & 1 & 10 & 10 & 12 & 12 & 12 \\
\hline Benzo $(g h i)$ perylene & & & & & & & & & & & 12 & 12 & 12 \\
\hline Chrysene & & & & & & & & & & & 12 & 12 & 17 \\
\hline Dibenz(ah)anthracene & & 0.1 & 1 & 1 & 10 & 10 & 0.1 & 1 & 10 & 10 & 1.2 & 1.2 & 1.9 \\
\hline Fluoranthene & & & & & & & & & & & 40 & 40 & 40 \\
\hline Fluorene & & & & & & & & & & & 340 & 340 & 340 \\
\hline Indeno(123-cd)pyrene & & 0.1 & 1 & 1 & 10 & 10 & 0.1 & 1 & 10 & 10 & 12 & 12 & 19 \\
\hline Naphthalene & & 0.1 & 5 & 5 & 50 & 50 & 0.1 & 0.6 & 22 & 22 & 4.6 & 4.6 & 4.6 \\
\hline Phenanthrene & & 0.1 & 5 & 5 & 50 & 50 & 0.1 & 5 & 50 & 50 & 40 & 40 & 40 \\
\hline Pyrene & & 0.1 & 10 & 10 & 100 & 100 & 0.1 & 10 & 100 & 100 & 250 & 250 & 250 \\
\hline
\end{tabular}

PAH (total of 10$)^{\mathrm{a}} \quad 1$

Abbreviations: BC Ag: British Columbia Agricultural; BC UP: British Columbia Urban Park; BC R: British Columbia Residential; BC C: British Columbia Commercial; BC I: British Columbia Industrial; CCME Ag: Canadian Council of Ministers of the Environment Agricultural; CCME RP: Canadian Council of Ministers of the Environment Residential/Parkland; CCME C: Canadian Council of Ministers of the Environment Commercial; CCME I: Canadian Council of Ministers of the Environment Industrial; Ont Ag (C): Ontario Agricultural land use (coarse- $\mu$ g/g); Ont RP (C): Ontario Residential/Parkland land use (coarse$\mu \mathrm{g} / \mathrm{g}$ ); Ont IC (C): Ontario Industrial/Commercial land use (coarse- $\mu \mathrm{g} / \mathrm{g}$ ); RIVM TV: The Netherlands soil/sediment (mg/kg dry material) target value.

a The total of anthracene, benzo $(a)$ anthracene, benzo $(k)$ fluoroanthene, benzo $(a)$ pyrene, chrysene, phenanthrene, fluoroanthene, indeno(123-cd)pyrene, naphthalene and benzo(ghi)perylene. 
may be pre-determined by soil organic carbon contents, despite the fact that the input of PAHs to each site is rather different.

\section{Conclusions}

Data from the current study demonstrated that urban soils from Beijing, China, were contaminated with PAHs ranging from 366 to $27,825 \mathrm{ng}^{-1}$. Based on the molecular indices (phenanthrene/anthracene and fluoranthene/pyrene ratios) of PAHs in soils, it was suggested that PAHs in soils from urban areas of Beijing had strong pyrogenic source. PAHs with 2-4 rings were the major fractions of the total soil PAHs. Total concentrations of PAHs in soils were strongly correlated with soil organic carbon (SOC), implying that SOC was the key factor determining the retention of PAHs in soils.

\section{Acknowledgements}

This work was supported by the Chinese Academy of Sciences (KZCX3-SW-424) and the Natural Science Foundation of China (Grant No. 40235054). The authors thank Ms. Jing Duan for her help in collecting soil samples and Ms. Qingcai Feng for her assistance in GC-MS analysis.

\section{References}

Alberty RA, Reif AK. Standard chemical thermodynamic properties of polycyclic aromatic hydrocarbons and their isomer groups I Benzene series. J Phys Chem Ref Data 1988;17:241-53.

Baumard P, Budzinski H, Michon Q, Garrigues P, Burgeot T, Bellocq J. Origin and bioavailability of PAHs in the Mediterranean Sea from mussel and sediment. Estuar Coast Shelf Sci 1998;47:77-90.

BCME (British Columbia Ministry of the Environment). Overview of CSST procedures for the derivation of soil quality matrix standards for contaminated sites. Victoria, Canada: BCME, Risk Assessment Unit; 1996. $51 \mathrm{pp}$.

Boehm PD, Burns WA, Page DS, Bence AE, Mankiewicz PJ, Brown JS, et al. Total organic carbon, an important tool in an holistic approach to hydrocarbon source fingerprinting. Environ Forensics 2002;3:243-50

CCME (Canadian Council of Ministers of the Environment). A protocol for the derivation of environmental and human health soil quality guidelines. CCME-EPC-101E. Ottawa, Canada; 1996a. 169 pp.

CCME (Canadian Council of Ministers of the Environment). Guidance manual for developing site-specific soil quality remediation objectives for contaminated sites in Canada. En-108-4/9 1996E. Ottawa, Canada; 1996b. 45 pp.

Chiou CT, Peters LJ, Freed VH. A physical concept of soil-water equilibria for nonionic organic compounds. Science 1979;206:831-2.

Chiou CT, McGroddy SE, Kile DE. Partition characteristics of polycyclic aromatic hydrocarbons on soils and sediments. Environ Sci Technol 1998;32:264-9.

Chu S-G, Liu H, Ma L-L, Xu X-B. Polycyclic aromatic hydrocarbons in soil adjacent to highways in Beijing, People's Republic of China. Environ Contam Toxicol 2003;70:972-7.

Chung N, Alexander M. Differences in sequestration and bioavailability of organic compounds aged in dissimilar soils. Environ Sci Technol $1998 ; 32: 855-60$
Chung N, Alexander M. Effect of soil properties on bioavailability and extractability of phenanthrene and atrazine sequestered in soil. Chemosphere 2002;48:109-15.

Colombo JC, Pelletier E, Brochu C, Khalil M. Determination of hydrocarbon sources using $n$-alkanes and polyaromatic hydrocarbon distribution indexes Case study: Rio de La Plata Estuary, Argentina. Environ Sci Technol 1989;23:888-94.

De Vries W, Bakker DJ. Manual for calculating critical loads of heavy metals for terrestrial ecosystem: guidelines for critical limits, calculation methods and input data. TNO Institute of Environmental Sciences, Energy Research and Process Innovation. Den Helder, The Netherlands; 1998. $144 \mathrm{pp}$

Grimmer GG, editor. Environmental carcinogens: polycyclic aromatic hydrocarbons chemistry, occurrence, biochemistry, carcinogenicity. Boca Raton (FL): CRC Press; 1983.

Hoffman D, Wynder EL. Respiratory carcinogens Their nature and precursors. In: Westley $\mathrm{B}$, editor. Identification and measurement of environmental pollutants. Ottawa, Canada: National Research Council; 1971. p. 9-16.

Hoffman EJ, Mills GL, Latimer JS, Quinn JG. Urban runoff as a source of polycyclic aromatic hydrocarbons to coastal waters. Environ Sci Technol 1984;18:580-7.

Jones KC. Contaminant trends in soils and crops. Environ Pollut 1991;69:311-25

Jonker MTO, Smedes F. Preferential sorption of planar contaminants in sediments from Lake Ketelmeer, the Netherlands. Environ Sci Technol 2000;34:1620-6.

Karickhof SW, Brown DS. Sorption of hydrophobic pollutants on natural sediments. Water Res 1979;13:241-8.

Lodovici M, Dolara P, Taiti S, Carmine PD, Bernardi L, Agati L, et al. Polynuclear aromatic hydrocarbons in the leaves of the evergreen tree (Laurus nobilis). Sci Total Environ 1994;153:61-8.

Mai B, Qi S, Zeng EY, Yang Q, Zhang G, Fu J, et al. Distribution of polycyclic aromatic hydrocarbons in the coastal region off Macao, China: assessment of input sources and transport pathways using compositional analysis. Environ Sci Technol 2003;37:4855-63.

McGroddy SE, Farrington JW. Sediment porewater partitioning of polycyclic aromatic hydrocarbons in three cores from Boston Harbor, Massachusetts. Environ Sci Technol 1995;29:1542-50.

Means JC, Wood SG, Hassett JJ, Banwart WL. Sorption of polynuclear aromatic hydrocarbons by sediments and soils. Environ Sci Technol 1980;14:1524-8.

Ministry of Environment and Energy (MOEE). Guideline for use at contaminated sites; 1996. http://www.ene.gov.on.ca; 83 pp.

Nelson DW, Sommers LE. Total carbon, organic carbon, and organic matter. In: Page AL, Miller RH, Keeney DR, editors. Methods of soil analysis (Part 2, Chemical and Microbiological Properties, second edition). Madison, WI, USA: ASA-SSSA; 1982. p. 539-79.

Perera FP. Environment and cancer: who are susceptible? Science 1997;278:1068-73.

Ribes A, Grimalt JO, Torres Garcia CJ, Cuevas E. Polycyclic aromatic hydrocarbons in mountain soils of the subtropical Atlantic. J Environ Qual 2003;32:977-87.

Sanders M, Sivertsen S, Scott G. Origin and distribution of polycyclic aromatic hydrocarbons in surficial sediments from the Savannah River. Arch Environ Contam Toxicol 2002;43:438-48.

Sicre MA, Marty JC, Saliot A. Aliphatic and aromatic hydrocarbons in different sized aerosols over the Mediterranean sea: occurrence and origin. Atmos Environ 1987;21:2247-59.

Simoneit BRT. Diterpenoid compounds and other lipids in deep-sea sediment and their geochemical significance. Geochim Cosmochim Acta 1977;41:463-76.

Solco H. Etude de la Distribution des Hydrocarbures Aromatiques Polycycliques dans les Sédiments Marins Récents, Identification des Sources. PhD thesis, University Bordeaux, France; 1986. 158 pp.

Sun YZ, Zhang HJ, Du ZC, Li QX, Li ZX. Organic pollution of street dust in the Handan City, China. Environ Contam Toxicol 2003;70:422-9. 
Wagrowski DM, Hites RA. Polycyclic aromatic hydrocarbon accumulation in urban, suburban, and rural vegetation. Environ Toxicol Chem 1997;31:2879-82.

Wakeham SG, Schaffner C, Giger W. Polycyclic aromatic hydrocarbons in recent lake sediment - I. Compounds having anthropogenic origins. Geochim Cosmochim Acta 1980;44:403-13.

Wakeham SG, Schaffner C, Giger W. Polycyclic aromatic hydrocarbons in recent lake sediment-II Compounds derived from biogenic precursors during early diagenesis. Geochim Cosmochim Acta 1980; 44:415-29.

Wang DT, Meresz O. Occurrence and potential uptake of polynuclear aromatic hydrocarbons of highway traffic origin by proximally grown food crops. In: Cooke M, Dennis AJ, Fisher GL, editors. Sixth Int
Symp, polynuclear aromatic hydrocarbons: physical and biological chemistry. New York: Springer Verlag; 1982. p. 885-96.

Wild SR, Jones KC. Biological and abiotic losses of polycyclic aromatic hydrocarbons (PAHs) from soils freshly amended with sewage sludge. Environ Toxicol Chem 1993;12:5-12.

Yunker MB, Snowdon LR, MacDonald RW, Smith JN, Fowler MG, Skibo $\mathrm{DN}$, et al. Polycyclic aromatic hydrocarbon composition and potential sources for sediment samples from the Beaufort and Barents seas. Environ Sci Technol 1996;30:1310-20.

Yunker MB, Macdonald RW, Gpyette D, Paton DW, Fowler BR, Sullivan D, et al. Natural and anthropogenic inputs of hydrocarbons to the Strait of Georgia. Sci Total Environ 1999;225:181-209. 